$\xi=$

\title{
Mini review on Incorporation of Cotton Seed Meal, an Alternative to Fish Meal in Aquaculture Feeds
}

\author{
B. Pavan Kumar ${ }^{1 *}$, Kurva Raghu Ramudu ${ }^{2}$, B.Chamundeswari Devi ${ }^{3}$ \\ ${ }^{1}$ Fisheries Development Officer, Uppada, A.P., India \\ ${ }^{2}$ Scientist (On contractual Basis), Fisheries Research Station, Sri Venkateswara Veterinary University, Kakinada-533 002, A.P., India \\ ${ }^{3}$ Principal Scientist \& Head, Fisheries Research Station, Sri Venkateswara Veterinary University, Kakinada-533 002, A.P., India \\ *Corresponding author E-mail: bpavankumar2@gmail.com
}

\begin{abstract}
Fish nutrition has advanced dramatically in recent years with the development of new balanced commercial diets that promote best fish growth and health. Feed accounts for a major part (30-70\%) of the total operation cost of an average fish farm. Traditionally, animal protein sources, particularly fishmeal have been the major ingredient of aqua feeds. Fishmeal is one of the most expensive ingredients in formulated fish feeds. Due to increasing demand, decreasing supply and the high cost of fish meal, fish nutritionists have concentrated their efforts to find alternative protein sources to substitute fish meal in the diet of fish. Thus, cottonseed meal (CSM), a by-product of the cotton fiber and cottonseed oil industries, may be used to replace fish meal partially or totally in fish diets. However, the cottonseed meal was evaluated by its anti-nutritional factors and its impact on the growth, survival, carcass composition and histopathology of fishes. It is observed that the more research is concentrated on the gossypol content in the cottonseed meal which is described as the antinutritional factor that shows high impact on the growth, carcass composition and pathological changes in the fish. Hence, considering these problems it is advised to use low levels of cottonseed meal in the aqua feeds. The gossypol level can be minimized by the solvent extracted cottonseed meal and be counteracted by the fortification of lysine and adding up of required iron levels. Further research may be required in histopathological studies to assess the toxicity levels in the tissues of the fish due to the gossypol factor.
\end{abstract}

Keywords: Cotton Seed Meal, Fish Meal, Gossypol.

\section{Introduction}

Worldwide aquaculture industry depends on the availability of low cost, high quality feeds. Due to increasing demand, decreasing supply and the high cost of fishmeal, fish nutritionists have concentrated their efforts to find alternative sources of proteins to substitute fishmeal in the diet of fish. However, interrelationships between nutrition, immunity and disease resistance in fish are poorly understood. Feed costs have been identified as an important constraint for the aquaculture development. Coyle et al. (2004) reported that feed costs account for more than $50 \%$ of total production costs in aquaculture because of the use of the expensive protein source, fishmeal. Many studies have been conducted to search for less expensive protein sources to replace fishmeal.

Plant proteins are widely used in feeds for aquaculture species. Global availability and relatively low cost compared to ingredients of animal origin and their most obvious positive attributes. Properly processed plant products and by-products generally also have the high protein digestibility. They can often be used in combination to replace more expensive ingredients like fishmeal without exception. Robinson and $\mathrm{Li}$ (1994) recommended that plant proteins can be used as a total replacement for animal protein without detrimental effects. Protein of plant origin is preferred as compared to animal origin protein in the culture of carps (Singh et al. 2004). Complex mixture of plant ingredients can serve as a replacement for fishmeal (Borgeson et al. 2006). Hardy (2006) reported that dietary replacement of fishmeal by plant origin by- products, such as soybean meal, cottonseed meal and rapeseed meal has been increasing in the aquaculture industry because of their low price, high market availabilities and sufficient protein contents.

\section{Cotton seed meal}

Cottonseed, Gossypium hirsute Linnaeus, is the third leading plant protein by weight (after soybean and rapeseed) used worldwide (Gatlin et al. 2007) and is available at relatively lower cost than animal proteins (Lovell 1989). According to National Cottonseed Production Association (NCPA) $450 \mathrm{Kgs}$ of cottonseed meal can be extracted from a ton of cottonseed crushed. Cottonseed meal can be obtained in two methods from cottonseed; one is through mechanical and the other by solvent extraction. However, the meal extracted from the both crude protein must contain not less than 36 percent (Blasi and Drouillard 2002) and the Proximate Composition of Cottonseed meal is showed in table. 1 (NRC, 1993).

Owing to its high protein value for human consumption (Alford et al. 1996) and animals, as well as low market price in comparison with other legumes and fishmeal, cottonseed meal (CSM) consequently has an immense potential for incorporation in high-protein aqua feeds (Gatlin et al. 2007). Nutritionally, cottonseed meal contains high levels of proteins (Forster and Cahloun 1995) and is very palatable to fish (Robinson and Li 1995).

The amount of CSM that can be included in feeds depends on the animal species, developmental stages, dietary protein, available 
lysine (Martin 1990) and levels of anti-nutritional factors. The level of cottonseed meal inclusion in fish varies widely among fish species such as tilapia, Sarotherodon mossambicus (Jackson et al. 1982), Oreochromis niloticus (Ofojekwu and Ejike 1984; ElSayed 1990; Rinchard et al. 2000; Mbahinzireki et al. 2001), Channel catfish, Ictalurus punctatus (Dorsa et al. 1982; Robinson et al. 1984b; Robinson and Brent 1989; Robinson and Li 1994; Robinson and Tiersch 1995), Chinook salmon, Oncorhynchus tshawytscha and Coho salmon, Oncorhynchus kisutch (Fowler 1980), Rainbow trout, Oncorhynchus mykiss (Dabrowski et al. 2000a,b; Dabrowski et al. 2001; Blom et al. 2001) and Labeo rohita (Usmani et al. 1997).

Table 1: Proximate Composition of Cottonseed Meal According to National Research Council (NRC). (NRC, 1993).

\begin{tabular}{ll}
\hline \multicolumn{2}{l}{ Proximate Composition of Cottonseed meal Solvent Extracted } \\
\hline International Feed Number 5-01-619 & $92 \%$ \\
Typical Dry Matter & $41.7 \%$ \\
Crude Protein & $1.8 \%$ \\
Crude Fat & $11.3 \%$ \\
Crude Fat & $6.4 \%$ \\
Ash & \\
Amino Acid Composition & $3.97 \%$ \\
Arginine & $0.83 \%$ \\
Histidine & $1.15 \%$ \\
Isoleucine & $1.8 \%$ \\
Leucine & $1.8 \%$ \\
lysine & $0.5 \%$ \\
Methionine & $0.45 \%$ \\
Cystine & $2.1 \%$ \\
Phenyl alinine & $0.8 \%$ \\
Tyrosine & $1.02 \%$ \\
Threonine & $0.42 \%$ \\
Tryptophan & $1.68 \%$ \\
Valine & \\
Mineral Composition & 0.17 \\
Calcium (\%) & 1.17 \\
Phosphorus (\%) & 1.39 \\
Potassium (\%) & 0.04 \\
Chlorine(\%) & 0.41 \\
Magnesium (\%) & 0.04 \\
Sodium (\%) & 0.30 \\
Sulphur (\%) & 19.00 \\
Copper (mg/kg) & 208.0 \\
Iron (mg/kg) & 21.0 \\
Magnesium (mg/kg) & 0.06 \\
Selenium (mg/kg) & 61 \\
Zinc (mg/kg) & \\
Vitamin Composition & $0.97 \mathrm{mg} / \mathrm{kg}$ \\
Biotin & $2764 \mathrm{mg} / \mathrm{kg}$ \\
Choline & $1.4 \mathrm{mg} / \mathrm{kg}$ \\
Folacin & $41 \mathrm{mg} / \mathrm{kg}$ \\
Niacin & $13.7 \mathrm{mg} / \mathrm{kg}$ \\
Pantothenic acid & $7 \mathrm{mg} / \mathrm{kg}$ \\
Pyridoxine & $3.3 \mathrm{mg} / \mathrm{kg}$ \\
Riboflavin & $6.6 \mathrm{mg} / \mathrm{kg}$ \\
Thiamine & - \\
Vitamin B12 & $16 \mathrm{mg} / \mathrm{kg}$ \\
Vitamin E & - \\
Vitamin K & \\
\hline
\end{tabular}

\section{Anti-nutritional factors}

The presence of anti-nutritional factors such as phytic acid, gossypol and cyclopropenoid acid limits the utilization of cottonseed meal in aquaculture diets.

\subsection{Phytic acid}

About $70 \%$ of the phosphorous in feedstuffs of plant origin is in the form of phytate, and its availability to fish is negligible (Ketola 1985). Phytates act as strong chelators and form protein-phytic acid complexes that may reduce the bio-availability of protein (Spinnelli et al. 1983) and minerals, such as zinc, manganese, copper, molybdenum, calcium, magnesium, and iron (Smith 1977).

\subsection{Cyclopropenoic fatty acids}

Cottonseed meal is the primary source of the cyclopropenoic fatty acids (CFAs) (sterculic acid and malvalic acid) in fish diets. CFAs are present in all varieties of cottonseed meal and are not completely removed by the oil extraction process (Mickelsen and Yang 1966). Dietary CFAs caused lesions, increased glycogen deposition, and elevated saturated fatty acid concentration in the liver in rainbow trout (Struthers et al. 1975a, b). The CFAs are powerful carcinogens when fed in combination with aflatoxins for rainbow trout (Hendricks et al. 1980) and sockeye salmon (Wales and Sinnhuber 1972). These compounds also induced hepatomas without aflatoxins in rainbow trout (Hendricks et al. 1980). Dietary CFAs alter the activity of several liver enzymes (Eisele et al. 1983), including the inhibition of fatty acid desaturases (Roehm et al. 1970) which may explain the accumulation of saturated fatty acids found in the liver of fish fed CFAs.

\subsection{Gossypol}

Many studies have showed that the amount of cottonseed meal (CSM) that can be used in fish feed depend mainly on the level of dietary free gossypol and available lysine content (Jones 1987; Robinson and Li 1994). CSM contains gossypol, a yellow cottonseed gland pigment, which is toxic to fish (Herman 1970; Rinchard et al. 2000) and terrestrial animals (Colin-Negrete et al. 1996) leading to a restriction of its use as a feed ingredient. Gossypols are polyphenols, present in the pigment glands of plants, mostly confined to the genus Gossypium (FAO 1983; Francis et al. 2001). The amount of gossypol in cottonseed varies according to the cotton species and certain environmental factors (Boatner et al. 1949; Cherry et al. 1978). Gossypol is available in either bound or free form; the bound form being non-toxic and of little significance since it is unavailable and passes through the gastrointestinal tract unabsorbed (Evans 1985 and Tanksley 1990) but the free form is highly toxic (Ogunji 2004)

A dietary level of $0.03 \%$ free gossypol suppressed growth rate and a level as low as $0.01 \%$ caused liver damage in rainbow trout (Herman 1970). Growth depression occurred in channel catfish fed diets containing more than $900 \mathrm{mg}$ free gossypol/kg diet (Dorsa et al. 1982). However, some fish species can tolerates higher gossypol concentrations, for instance tilapia has been fed up to $0.18 \%$ free gossypol with no adverse effect (Lovell 1998). CSM with low levels of gossypol performed excellently when fed to Oreochromis mossambicus (Jackson et al. 1982).

Gossypol appears to have detrimental effects on growth and feed efficiency parameters. Free gossypol is reported to be a membrane-active agent with cytocidal properties and the ability to inhibit membrane bound enzymes, causing hemolytic anemia at high concentrations (Makinde et al. 1997). Feeding diets containing gossypol causes negative effects, such as growth depression, intestinal and other internal organ abnormalities (Berardi and Goldblatt 1980). Gossypol has been shown to affect growth, feed intake, reproductive efficiency, erythrocyte numbers and oxygencarrying activity, respiration efficiency, and liver function (Lindsey et al. 1980 and Brocas et al. 1997). The toxic systemic effects of gossypol include reduced hematocrit, hemoglobin, reproductive capacity as well as lesions in liver, kidney, spleen and gonads in various fish species have been documented but the mechanisms behind the reduced growth and nutrient digestibility's are unknown (Anon 2009).

Gossypol can be partially or totally inactivated by heat treatment (Herkelman et al. 1991; Bollini et al. 1999; Elmaki et al. 2007), soaking (Rani and Hira 1993; Duhan et al. 2002; Elmaki et al. 2007), fermentation (Marfo et al. 1990; Antai and Nkwelang 1998) or supplementation of diets with enzymes hydrolysing specific antinutrients (Southern et al. 1990; Sandberg and Svanberg 1991; Cheng and Hardy 2002; Portz and Liebert 2004; Sajjadi and Carter 2004), amino acids ( $\mathrm{Li}$ and Robinson 1998; Fagbenro 1999) or minerals (Jones 1987; Martin 1990; El-Saidy and Gaber 2004). The amount of free gossypol in cottonseed meal depends 
upon processing (Lovell 1981). During processing, free gossypol is bound to cottonseed protein resulting in bound gossypol and unavailable amino acids. This binding reduces the protein quality, especially regarding to lysine availability. Lysine is believed to be the primary amino acid that is bound to free gossypol (Kuiken and Lyman 1948; Baliga and Lyman 1957; Conkerton et al. 1957). It is observed that supplementation of the Iron, as ferrous sulphate, has been used to bind with the toxic free gossypol and thereby reduce the toxicity for monogastric animals (Jones 1987; Martin 1990) and fish (Sealey et al. 1997; Barros et al. 2002). El-Saidy and Gaber (2004) observed improved growth, feed utilization, and blood parameters among fish fed a CSM diet containing 1:1 iron to free gossypol than among fish fed a CSM diet without iron supplementation. High levels of supplemental iron used to counteract the toxicity of gossypol may be harmful to fish because it has been suggested that a delicate balance exists between the need of iron for host defense mechanisms and the need of iron to sustain microbial growth (Barros et al. 2002). The effect of gossypol concentration studied by Lim and Lee (2008) supports the notion that lysine and iron supplementation into CSM containing diets reduce gossypol toxicities in fish (Robinson 1991; Robinson and Li 1994; Dabrowski et al. 2000a,b; Lee et al. 2006). Noteworthy is that acetone extraction apparently decreases gossypol and aflatoxin levels in the cottonseed meal more efficiently than hexane extraction and results in improved crude protein and amino acid digestibilities (Cheng and Hardy 2002). Yet the authors suggested a maximum inclusion level of $10 \%$ of acetone extracted cottonseed meal in diets for rainbow trout.

However, gossypol also has several desirable properties, including anti-parasitic, anti-bacterial, anti-viral, and antioxidant properties (Bickford et al. 1954; Margalith 1967; Montamat et al. 1982; Wichman et al. 1982 and Heidrich et al. 1983). Gossypol or other compounds present in CSM may have a beneficial effect by improving the immune response and the resistance of juvenile channel catfish against Edwardsiella ictaluri infection as evidence by increase in macrophage chemotaxis, improved survival and continued consumption of diets containing CSM (Barros et al. 2002). The Commission of the European Communities limits the amount of free gossypol in feed materials (with the exception of cottonseed, cottonseed meal and cottonseed cakes) at $20 \mathrm{mg} \mathrm{kg}^{-1}$ which did not cause reductions in growth and nutrient digestibility. However, the limits for cottonseed and cottonseed meal are 5,000 $\mathrm{mg} \mathrm{kg}^{-1}$ and 1,200 $\mathrm{mg} \mathrm{kg}^{-1}$, respectively (Anon 2009). The inclusion of cottonseed meal can be evaluated by the growth, survival, carcass composition and histopathology of fishes.

\section{Growth}

The term growth will signifies change in magnitude. The variables undergoing change may be the length or other physical dimensions, including volume, weight, or mass either of an organism's whole body or its various tissues or it may relate to lipids, protein content, or other chemical constituent of the body (Weatherly and Gill 1987).

The growth and feed conversion ratio (FCR) of a fish is remarkable tool to compute the acceptability of artificial feed. Barros et al (2002) reported that the cottonseed meal (CSM) has a lower nutritional value than soybean meal (SBM), but CSM has some other important advantages such as lower FCR. This better performance might be attributed to its higher fibre quality. Sahzadi et al. (2006) suggested that cottonseed meal, because of growth performance and better FCR (2.17) can be included in the feed for hybrid fingerlings (Catla catla x Labeo rohita). Gui et al. (2010) studied on weight gain, food conversion ratio (FCR) and total tract apparent digestibility (CTTAD) of the crucian carp (Carassius auratus gibelio) and observed a positive effect on growth and feed utilization when cottonseed meal hydrolysate $(\mathrm{CMH})$ was used. They suggested that an approximate supplementation of $\mathrm{CMH}$ in practical diets is up to $50 \mathrm{~g} / \mathrm{kg}$. Usmani et al. (1997) observed that inclu- sion of glanded cottonseed meal more than $5.41 \%$ in the diet resulted in depressed growth in rohu, Labeo rohita.

The literature available on the effects of feeding CSM to tilapia is contradictory. Ofojekwu and Ejike (1984) reported a much lower weight gain and feed efficiency of Oreochromus niloticus fed with cottonseed cake diet compared with fishmeal based diet. Robinson et al. (1984a) reported that neither glanded nor glandless cottonseed meals appeared to be as high in nutritive value for Tilapia sp. as soybean and peanut meals. However they reported that tilapia can tolerate gossypol acetate supplemented to purified diets up to $0.2 \%$ with no decrease in growth. Jackson et al. (1982) obtained good growth of tilapia (Sarotherodon mossambicus) when $35.2 \%$ prepressed, solvent extracted CSM (0.03\% free gossypol) was used as a substitute for $50 \%$ of fishmeal protein. Viola and Zohar (1984) found that low gossypol cottonseed meal could be included in feeds for hybrid tilapia Oreochromis niloticus x Oreochromis aureus at the same levels as soybean meal. El-Sayed (1990) demonstrated that CSM could be used as a main dietary protein source for Oreochromis niloticus. Mbahinzireki et al. (2001) recommended that CSM can partially replace FM as a main source of protein in feed for tilapia at not more than $50 \%$. Yue and Zhou (2008) conducted experiment on Oreochromis niloticus $\mathrm{x}$ O.aureus for replacement of soybean meal with cottonseed meal. They revealed that up to $60 \%$ of SBM could be replaced by CSM without causing a significant reduction in growth. Rinchard et al. (2002) recommended that CSM can be replaced up to $50 \%$ of fishmeal protein without compromising growth of tilapia. Nelson (2008) reported cost effectiveness of the diets containing mixtures, particularly those containing equal proportions of oilseed meals and higher proportion of CSM replacing between 50 to $75 \%$ fish meal protein. Based on growth performance, nutrient utilization and economic benefits the diet with heat processed oilseed meal mixtures (containing equal proportions of soybean meal, cottonseed meal and groundnut cake $16.67 \%$ each) at $50 \%$ inclusion has the best prospects for replacing FM protein in diets of Oreochromis niloticus.

Numerous studies have been conducted to determine the level of cottonseed meal that can be incorporated in channel catfish diets without affecting their growth performance (Dorsa et al. 1982; Robinson and Rawles 1983; Robinson et al. 1984a; Robinson and Daniels 1987; Robinson and Li 1994; Robinson and Tiersch 1995). Dorsa et al. (1982) recommended that glanded cottonseed meal should not exceed 12 to $15 \%$ of catfish diets. Robinson and Brent (1989) recommended that cottonseed meal can be used as partial substitute for soybean meal in catfish diets. They also suggested that cottonseed meal be limited to $15 \%$ of the catfish diet. Robinson and Li (1994) observed that cottonseed meal plus lysine can be used as total substitute for soybean meal in catfish diets. However it is not recommended that not more than $30 \%$ cottonseed meal be used in catfish feeds. Although solvent extracted SBM and CSM are often reported safe for fish, Toko et al. (2008) recommended that CSM and SBM can only partially replace fishmeal as a source of protein in compound feed for vundu catfish, Heterobranchus longifilis at a limited amount between 300 and $600 \mathrm{~g} / \mathrm{kg}$ for SBM and $<300 \mathrm{~g} / \mathrm{kg}$ for CSM.

Fowler (1980) demonstrated that up to $34 \%$ of CSM can be used in the diet for two Pacific salmon species (Chinook salmon and Coho salmon) to replace SBM without growth depression. Cheng and Hardy (2002) reported that the acceptable level of CSM inclusion in the ration of juvenile rainbow trout should not be higher than $10 \%$ and they suggested that substitution of SBM by CSM more than $55 \%$ could result in reduced weight gain. Lee et al. (2002) suggested that CSM can be used as a good protein source by the incorporation of at least $15 \%$ in diets $(25 \%$ protein of fishmeal as a replacement). Lee et al. (2006) concluded that high dietary supplementation of CSM up to $58.8 / 100 \mathrm{~g}$ or its complete substitution for FM did not have detrimental effects on growth of rainbow trout brood stock. Dadgar et al. (2009) observed that Iranian CSM did not negatively affect weight gain (WG) even at $100 \%$ replacement for SBM and suggested that Iranian CSM can be included in the rainbow trout diet up to $310 \mathrm{~g} / \mathrm{kg}$. However Luo 
et al. (2006) stated that fish fed with diet with solvent extracted cottonseed meal at $100 \%$ level had significantly lower weight gain, specific growth rate, feed conversion efficiency and protein efficiency ratio than fish fed with other diets. They also recommended that solvent extracted cottonseed meal can be utilized in the juvenile rainbow trout diet up to $305 \mathrm{~g} / \mathrm{kg}$ to replace about $50 \%$ of fishmeal protein. Blom et al. (2001) recommended that CSM could be a suitable alternative for partial replacement of FM and SBM and it can totally replace them if used with supplementary lysine.

Lim and Lee (2008) concluded that the mixture of cottonseed with iron and phosphorus supplementation can be replaced up to $40 \%$ fishmeal protein in diets for olive flounder, Paralichthys olivaceus. However based on the tendency in growth performance, they suggested $30 \%$ of fishmeal protein replacement by CSM with supplementation of iron and phosphorus might be a safe level for commercial use. They also suggested that dietary supplementation of iron and phosphorus could increase the inclusion of CSM for fishmeal replacement in diets for marine fish species. In the same species Pham et al. (2007) shows that mixture of CSM and SBM with lysine and methionine supplementation can replace up to $30 \%$ fishmeal protein in diet for olive flounder at the early juvenile stage. However, they suggested that $20 \%$ fishmeal protein replacement by CSM (10\%) and soybean meal (10\%) can be optimum level as per the growth performance is considered. Lim and Lee (2009) concluded that the mixture of CSM and SBM with lysine and methionine supplementation can replace up to $20 \%$ fishmeal protein in diets for juvenile $(3-22 \mathrm{~g})$ parrot fish, Oplegnathus fasciatus. In growing (55 to $120 \mathrm{~g}$ ) parrot fish, fishmeal protein can be replaced up to $30 \%$ with CSM and SBM protein. They suggested up to about $30 \%$ fishmeal protein can be replaced by an equal mixture of CSM and SBM with iron and phytase in the presence of lysine and methionine in practical diets for parrot fish.

\section{Carcass composition}

Body composition is a good indicator of the physiological condition of a fish but it is relatively time consuming to measure. Proximate body composition is the analysis of water, fat, protein and ash contents of fish. Carbohydrates and non-protein compounds are present in negligible amount (Cui and Wootton, 1988). The percentage of water is a good indicator of its relative contents of energy, proteins and lipids. Dempson et al. (2004) reported that lower the percentage of water, greater the lipids and protein contents and higher the energy density of the fish. However, these values vary considerably within and between species, size, sexual condition, feeding, season and physical activity. Protein content, which is an important component, tends to vary little in healthy fish (Weatherly and Gills 1987).

Plant based feeds significantly raises the protein and fat levels in the carcass composition of major carps (Nandeesha et al. 1995). Both animal and plant based diets lower the moisture level (Nandeesha et al. 2002) and do not show prominent effects on ash contents (Garg et al. 2002). In Atlantic cod, phosphorus supplementation in plant protein based diets could replace 50\% dietary FM without growth impairment (Albrektsen et al. 2006).

According to Usmani et al. (1997) the analysis of body composition of Labeo rohita revealed that the crude protein and ash content did not vary among the fish groups receiving various levels of cottonseed meal in the diet. Fat and moisture, however, showed a gradual decline in fish beyond $5.41 \%$ dietary cottonseed meal inclusion. Gui et al. (2010) observed no marked differences in the contents of lipid and ash in the body composition of crussian carp in all groups fed with cottonseed meal hydrolysate at different levels. Furthermore, the contents of Zinc and Fe increased in fish fed $50 \mathrm{~g} / \mathrm{kg}$ cottonseed meal hydrolysate and $100 \mathrm{~g} / \mathrm{kg}$ cottonseed meal hydrolysate. Toko et al. (2008) observed the whole body content of calcium $(\mathrm{Ca})$, phosphorus $(\mathrm{P})$, potassium $(\mathrm{K})$, zinc $(\mathrm{Zn})$ and manganese $(\mathrm{Mn})$ were markedly affected by dietary SBM level at high inclusions while increasing dietary CSM did not affect the content of these elements in carcass. Pham et al. (2007) recommended that replacement of fishmeal protein up to $40 \%$ level by cottonseed meal and soybean meal by equal proportion with L-methionine and L-lysine supplementation did not affect the whole body compositions of Japanese flounder, Paralichthys olivaceus.

\section{Histopathology}

Although toxicant impairs the metabolic and the physiological activities of the organism, physiological studies alone do not satisfy the complete understanding of pathological conditions of tissues under toxic stress. Hence, it is useful to have an insight into histological analysis, as they act as biological markers to assess the toxicity condition (Rao et al. 1985; Tilak et al. 2001; Srivastava et al. 2008).

Evans et al. (2010) observed in their study and also those by Herman (1970) and Barros et al. (2000) that inclusion of gossypol in the diet had no statistically significant effect on liver glycogen deposition. Herman (1970) observed liver necrosis in rainbow trout fed diets containing gossypol. Barros et al. (2000) observed pancreas and liver necrosis in catfish fed diets of control or 55\% CSM and suggested that more research was required to determine whether the components of CSM could cause necrosis. Roehm et al. (1967) reported that the amount of total and free gossypol were the highest in liver than in any other tissue determined in rainbow trout.

Yildirim et al. (2003) studied on the histological and histochemical changes among juvenile channel catfish, Ictalurus punctatus, fed purified diets containing graded levels of gossypol from gossypol-acetic acid. They observed that feed intake, feed efficiency, weight gain, whole body lipid and protein, red blood cell (RBC) counts, haemoglobin, hematocrit and serum protein decreased with increasing dietary gossypol concentration. Whole body moisture, body ash, hepatic gossypol concentrations and serum lysozyme activity were increased with increasing dietary gossypol and superoxide anion production and survival were not affected by dietary gossypol. Macrophage chemotaxis was lower for all gossypol fed fish than controls.

\section{Conclusion}

Cottonseed meal is a high level protein source and economically viable for including it in the aqua feeds. However, there are some detrimental effects observed in inclusion of CSM, It is obvious that the answer is not for the complete removal of CSM in the inclusion of aqua feeds since, the higher protein level and good economic viability. Hence, it is recommended that low level of CSM can be included in the aqua feeds. Besides, fortification of lysine and adding up of required iron level would increase the inclusion of CSM. Moreover it is advised to use the solvent extracted cottonseed meal rather than the glanded cottonseed meal since, the gossypol level is low and protein level is high than the latter. Apart from the physiological index of fish, impact of toxicity from the components of cottonseed meal can be understood by the pathological studies. More research is required in this aspect to know the requirement of the cottonseed meal in the diets of fishes.

\section{References}

[1] Albrektsen S, Mundheim H and Aksnes A (2006) Growth, feed efficiency, digestibility and nutrient distribution in Atlantic cod (Gadus morhua) fed two different fish meal qualities at three dietary levels of vegetable protein sources. Aquaculture 261: 626-640. http://dx.doi.org/10.1016/j.aquaculture.2006.08.031.

[2] Alford BB, Liepa GU and Vanbeber AD (1996) Cottonseed protein: what does the future hold? Plant Foods Human Nutrition 49:1-11. http://dx.doi.org/10.1007/BF01092517. 
[3] Anon (2009) Criteria for safe use of plant ingredients in diets for aquacultured fish - Opinion of the Panel on Animal Feed of the Norwegian Scientific Committee for Food Safety, Norwegian Scientific Committee for Food Safety (VKM) P:18

[4] Antai SP and Nkwelang G (1998) Reduction of some toxicants in Icacina mannii by fermentation with Saccharomyces cerevisiae. Plant Foods Human Nutrition 53:103-111. http://dx.doi.org/10.1023/A:1008060029175.

[5] Baliga BP and Lyman CM (1957) Preliminary report on the nutritional significance of bound gossypol in cottonseed meal. Journal of the American Oil Chemists' Society, 34:21. http://dx.doi.org/10.1007/BF02637931.

[6] Barros MM, Lim C and Klesius PH (2002) Effect of soybean meal replacement by cottonseed meal and iron supplementation on growth, immune response and resistance of Channel Catfish (Ictalurus punctatus) to Edwardsiella ictaluri challenge. Aquaculture 207:263279. http://dx.doi.org/10.1016/S0044-8486 (01)00740-2.

[7] Barros MM, Lim C, Evans JJ and Klesius PH (2000) Effect of iron supplementation to cottonseed meal diets on the growth performance of channel catfish, Ictalurus punctatus. Journal of Applied Aquaculture 10:65-86. http://dx.doi.org/10.1300/J028v10n01_07.

[8] Berardi LC and Goldblatt LA (1980) Gossypol. I. E. Liener, editor Toxic constituents of plant foodstuffs, second edition. Academic Press. New York, USA. PP: 183-237

[9] Bickford WG, Pack FC, Castillon LE and Mack CH (1954) the antioxidant and antipolymerization properties of gossypol, dianilinogossypol and related materials. Journal of the American Oil Chemists' Society 31:91-92. http://dx.doi.org/10.1007/BF02612489.

[10]Blasi DA and Drouillard J (2002) Cottonseed Feed Products for Beef Cattle, Composition and Feeding Value, Kansas State University. P: 22.

[11]Blom JH, Lee KJ, Rinchard J, Dabrowski K and Ottobre J (2001) Reproductive efficiency and maternal-offspring transfer of gossypol in rainbow trout (Oncorhynchus mykiss) fed diets containing cottonseed meal. Journal Animal Science 79:1533-1539.

[12]Boatner CH, Castillon LE and Hall CM (1949) Gossypol and gossypurpurin in cottonseed of different varieties of G. barbadense and $\mathrm{G}$. hirsutum, and variation of the pigments during storage of the seed. Journal of the American Oil Chemists' Society 26:19-25. http://dx.doi.org/10.1007/BF02634832.

[13]Bollini RE, Carnovale and CampionB (1999) Removal of antinutritional factors from bean (Phaseolus vulgaris L.) seeds. Biotechnology, Agronomy, Society and Environment 3:217-219.

[14]Borgeson TL, Racz VJ, Wilkie DC, White LJ and Drew MD (2006) Effect of replacing fishmeal and oil with simple or complex mixtures of vegetable ingredients in diets fed to Nile tilapia (Oreochromis niloticus). Aquaculture Nutrition 12(2):141-149. http://dx.doi.org/10.1111/j.1365-2095.2006.00394.x.

[15]Brocas C, Rivera RM, Paula-Lopez FF, Mc Dowell LR, Calhoun MC Staples CR, Wilkinson NS, Boning AJ, Chenoweth PJ and Hansen PJ (1997) Deleterious actions of gossypol on bovine spermatozoa, oocytes and embryos. Biology of Reproduction 57:901-907. http://dx.doi.org/10.1095/biolreprod57.4.901.

[16]Cheng ZJ and Hardy RW (2002) apparent digestibility coefficients and nutritional value of cottonseed meal for rainbow trout (Oncorhynchus mykiss). Aquaculture 212:361-372. http://dx.doi.org/10.1016/S0044-8486 (02)00260-0.

[17]Cherry JP, Simmons JG and Koheel RJ (1978) Cottonseed composition of national variety test cultivars grown in different Texas locations. In: Proceedings of the Beltwide Cotton Production Research Conference (Brown, J.M. edition.) 1978, Dallas, Texas. pp. 47-58

[18]Colin-Negrete J, Kiesling HE, Ross TT and Smith JF (1996) Effect of whole cottonseed on serum constituents, fragility of erythrocyte cells, and reproduction of growing Holstein heifers. Journal of Dairy Science 79:2016. http://dx.doi.org/10.3168/jds.S0022-0302 (96)76574-8.

[19]Conkerton EJ, Martinez WH, Mann GE and Frampton VL (1957) Changes induced by autoclaving a solvent extracted cottonseed meal Journal of Agricultural and Food Chemistry 5:460. http://dx.doi.org/10.1021/jf60076a011.

[20]Coyle SD, Mengel GJ, Tidwell JH and Webster CD (2004) Evaluation of growth, feed utilization, and economics of hybrid tilapia, Oreochromis niloticus x Oreochromis aureus, fed diets containing different protein sources in combination with distillers dried grains with solubles. Aquaculture Research 35(4):365-370 http://dx.doi.org/10.1111/j.1365-2109.2004.01023.x.

[21]Cui Y and Wootton RJ (1988) Bioenergetics of growth of Cyprinids, Phoxinus, the effect of the ration and temperature on growth rate and efficiency. Journal of Fish Biology 33:763-773. http://dx.doi.org/10.1111/j.1095-8649.1988.tb05521.x.
[22]Dabrowski K, Lee KJ, Rinchard J, Ciereszko A, Blom JH and Ottobre J (2001) Gossypol isomers bind specifically to blood plasma proteins and spermatozoa of rainbow trout fed diets containing cottonseed meal. Biochimica et Biophysica Acta General Subjects. 1525:37-42. http://dx.doi.org/10.1016/S0304-4165 (00)00168-9.

[23]Dabrowski K, Rinchard J, Ciereszko A, Lee KJ and Czesny S (2000b) Effects of gossypol containing diets on the viability of male and female gametes in rainbow trout (Oncorhynchus mykiss). 130th Annual Meeting American Fisheries Society, St. Louis, Missouri, USA, 2000b, p.171.

[24]Dabrowski K, Rinchard J, Lee KJ, Blom JH, Ciereszko and Ottobre J (2000a) Effects of diets containing gossypol on reproductive capacity of rainbow trout (Oncorhynchus mykiss). Biology of Reproduction 62:227-234. http://dx.doi.org/10.1095/biolreprod62.2.227.

[25]Dadgar S, Saad CR, Kamarudin MS, Alimon AR, Harmin SA, Satar MKA, Arshad A and Nafisi M (2009) Partial or Total Replacement of Soybean Meal with Iranian Cottonseed Meal in Diets for Rainbow Trout (Oncorhynchus mykiss). Research Journal Fishery Hydrobiology 4(1):22-28.

[26]Dempson IB, Schwarz CJ, Shears M and Furey G (2004) Comparative proximate body composition of Atlantic salmon with emphasis on parr from fluvial and lacustrine habitats. Journal Fish Biology 64:12571271. http://dx.doi.org/10.1111/j.0022-1112.2004.00389.x.

[27]Dorsa WJ, Robinette HR, Robinson EH and Poe WE (1982) Effects of dietary cottonseed meal and gossypol on growth of young channel catfish. Trans American Fishery Society 111:651-655. http://dx.doi.org/10.1577/1548-8659 (1982)111<651: EODCMA>2.0.CO; 2.

[28]Duhan A, Khetarpaul N and Bishnoi S (2002) Change in phytates and HCL-extractability of calcium, phosphorus and iron of soaked, dehulled, cooked, and sprouted pigeon pea cultivar. Plant Foods for Human Nutrition http://dx.doi.org/10.1023/A:1021814919592.

[29]Eisele TA, Coulombe RA, Williams JL, Shelton DW and Nixon JE (1983) Time-dependent and dose-dependent effects of dietary cyclopropenoid fatty acids on the hepatic microsomal mixed function oxidase system of rainbow trout Salmo gairdneri. Aquatic Toxicology 4: 139-148. http://dx.doi.org/10.1016/0166-445X (83)90051-6.

[30]Elmaki HB, AbdelRahaman SM, Idris WH, Hassan AB, Babiker EE and El-Tinay AH (2007) Content of antinutritional factors and HCLextractability of minerals from white bean (Phaseolus vulgaris) cultivars: influence of soaking and/or cooking. Food Chemistry 100:362 368. http://dx.doi.org/10.1016/j.foodchem.2005.09.060.

[31]El-Saidy DMSD and Gaber MM (2004) Use of cottonseed meal supplemented with iron for detoxification of gossypol as a total replacement of fish meal in Nile tilapia, Oreochromis niloticus (L.) diets. Aquaculture Research 35:859-865. http://dx.doi.org/10.1111/j.13652109.2004.01077.x

[32]El-Sayed AFM (1990) Long-term evaluation of cottonseed meal as a protein source for Nile tilapia, Oreochromis niloticus (Linn.). Aquaculture 84(3 - 4):315-320.

[33]Evans JJ, Pasnik DJ, Yildirim-Aksoy M, Lim C and Klesius PH (2010) Histologic changes in channel catfish, Ictalurus punctatus Rafinesque fed diets containing graduate levels of gossypol acetic acid Aquaculture Nutrition 16:385-391. http://dx.doi.org/10.1111/j.13652095.2009.00676.x.

[34]Evans M (1985) Nutrient composition of feedstuffs for pigs and poultry. Brisbane/Australia: Queensland Dept. of Primary Industries Information Series Q185001.

[35]Fagbenro OA (1999) Comparative evaluation of heat-processed winged bean (Psophocarpus tetragonolobus) meals as partial replacement for fish meal in diets for the African catfish (Clarias gariepinus). Aquaculture 170:297-305. http://dx.doi.org/10.1016/S0044-8486 (98)00409-8

[36]FAO (1983) Fish feeds and feeding in developing countries - An Interim Report on the ADCP Feed Development Programme. FAO (ADCP/Rep/83/18). Rome, Italy: Food and Agriculture Organization of the United Nations.

[37]Forster LA and Cahloun MC (1995) Nutrient values for cottonseed product deserve new look. Feedstuffs 67:1-5.

[38]Fowler LG (1980) Substitution of soybean and cottonseed products for fish meal in diets fed to Chinook and Coho salmon. Progressive Fish-Culturist 42:87-91. http://dx.doi.org/10.1577/1548-8659 (1980)42[87: SOSACP] 2.0.CO; 2.

[39]Francis G, Makkar HPS and Becker K (2001) Antinutritional factors present in plant-derived alternate fish feed ingredients and their effects in fish. Aquaculture 199 (3-4):197-227. http://dx.doi.org/10.1016/S0044-8486 (01)00526-9.

[40]Garg SK, Kalla A and Bhatnagar A (2002) Evaluation of raw and hydrothermically processed leguminous seeds as supplementary feed 
for the growth of two Indian major carp species. Aquaculture Research 33:151-163. http://dx.doi.org/10.1046/j.1365 2109.2002.00642.x.

[41]Gatlin III DM, Barrows FT, Brown P, Dabrowski K, Gaylord TG Hardy RW, Herman E, Hu G, Krogdahl A, Nelson R, Overturf K, Rust M, Sealey W, Skonberg D and Souza EJ (2007) Expanding the utilization of sustainable plant products in aquafeeds: a review. Aquaculture Research 38:551-579. http://dx.doi.org/10.1111/j.13652109.2007.01704.x.

[42]Gui D, Liu W, Shao X and Xu W (2010) Effects of different dietary levels of cottonseed meal protein hydrolysate on growth, digestibility, and body composition and serum biochemical indices in crucian carp (Carassius auratus gibelio). Animal Feed Science and Technology 156:112-120. http://dx.doi.org/10.1016/j.anifeedsci.2010.01.012.

[43]Hardy RW (2006) World fishmeal production outlook and the use of alternative protein meals for aquaculture. Avances en Nutrition Acuicola VII. (Ed. E.C. Suarez et al.,) VIII. Simposium Internationa de Nutrition Acuicola, 15-17 Noviebre, Universidad Autonoma de Nuevo Leon, Mexico. pp.410-419.

[44]Heidrich JE, Hunsaker LA and Vander Jagt DL (1983) Gossypol, an antifertility agent, exhibits anti-malarial activity in vitro. IRCS journal of medical science 11:304.

[45]Hendricks JD, Sinnhuber RO, Loveland PM, Powlowski NE and Nickson JE (1980) Hepatocarcinogenicity of glandless cottonseeds and cottonseed oil to rainbow trout (Salmo gairdneri). Science 208 309-311. http://dx.doi.org/10.1126/science.6892734.

[46]Herkelman KL, Cromwell GL and Stahly TS (1991) Effects of heating time and sodium metabisulfite on the nutritional value of full-fat soybeans for chicks. Journal of Animal Science 69:4477-4486.

[47]Herman RL (1970) Effects of gossypol on rainbow trout Salmo gairdneri Richardson. Journal of Fish Biology 2:293. http://dx.doi.org/10.1111/j.1095-8649.1970.tb03288.x.

[48]Jackson AJ, Capper BS and Matty AJ (1982) Evaluation of some plant proteins in complete diets for the tilapia Sarotherodon mossambicus. Aquaculture 27:97-09. http://dx.doi.org/10.1016/0044-8486 (82)90129-6.

[49]Jones LA (1987) Recent advances in using cottonseed products. In Proceedings of the Florida Nutrition Conference, 12-13 March 1987, Daytona Beach, FL, pp.119-138.

[50]Ketola HG (1985) Mineral nutrition: Effects of phosphorus in trout and salmon feeds on water pollution. In Nutrition and Feeding of Fish, C. B. Cowey, A. M. Mackie, and J. G. Bell, eds. New York: Academic Press. PP. 465-473.

[51]Kuiken KA and Lyman CM (1948) Availability of amino acids in some foods. Journal of Nutrition 36:359.

[52]Lee KJ, Dabrowski K, Blom JH, Bai SC and Stromberg PC (2002) A mixture of cottonseed meal, soybean meal and animal by product mixture as a fish meal substitute: growth and tissue gossypol enantiomers in juvenile rainbow trout (Oncorhynchus mykiss). Journal of Animal Physiology and Animal Nutrition 86:201-213. http://dx.doi.org/10.1046/j.1439-0396.2002.00375.x.

[53]Lee KJ, Rinchard J, Dabrowski K, Babiak I, Ottobre JS and Christensen JE (2006) Long-term effects of dietary cottonseed meal on growth and reproductive performance of rainbow trout: Three-year study. Animal Feed Science and Technology 126:93-106 http://dx.doi.org/10.1016/j.anifeedsci.2005.06.007.

[54]Li MH and Robinson EH (1998) Effects of supplemental lysine and methionine in low protein diets on weight gain and body composition of young channel catfish, Ictalurus punctatus. Aquaculture 163:297307. http://dx.doi.org/10.1016/S0044-8486 (98)00239-7.

[55]Lim SJ and Lee KJ (2009) Partial replacement of fishmeal by cottonseed meal and soybean meal with iron and phytase supplementation for parrot fish Oplegnathus fasciatus. Aquaculture 290:283-289. http://dx.doi.org/10.1016/j.aquaculture.2009.02.018.

[56]Lim SJ and Lee KJ (2008) Supplemental iron and phosphorus increase dietary inclusion of cottonseed and soybean meal in olive flounder (Paralichthys olivaceus). Aquaculture Nutrition 14:423-430. http://dx.doi.org/10.1111/j.1365-2095.2007.00546.x.

[57]Lindsey TO, Hawkins GE and Guthrie LD (1980) Physiological responses of lactating cows to gossypol from cottonseed meal rations. Journal Dairy $\quad$ Science $63: 562-573$ http://dx.doi.org/10.3168/jds.S0022-0302 (80)82972-9.

[58]Lovell RT (1981) Cottonseed meal in fish feeds. Feedstuffs Minor 53 28.

[59]Lovell RT (1989) Nutrition and feeding of fish. New York, USA: Van Nostrand Reinhold, New York. http://dx.doi.org/10.1007/978-1-47571174-5.

[60]Lovell RT (1998) Nutrition and feeding of Fish. Second edition, Boston, MA; London: Kluwer Academic. http://dx.doi.org/10.1007/978-14615-4909-3
[61]Luo L, Xue M, Wu X, Cai X, Cao H and Liang Y (2006) Partial or total replacement of fishmeal by solvent-extracted cottonseed meal in diets for juvenile rainbow trout (Oncorhynchus mykiss). Aquaculture Nutrition 12:418-424. http://dx.doi.org/10.1111/j.13652095.2006.00443.x.

[62] Makinde MO, Akingbemi BT and Aire TA (1997) Gossypol-induced erythrocyte fragility in the rat is ameliorated by ethanol intake. South African Journal Science 93:141-143.

[63]Marfo EK, Simpson BK, Idowu JS and Oke OL (1990) Effect of local food processing on phytate levels in cassava, cocoyam, yam, maize, sorghum, rice, cowpea and soybean. Journal of Agricultural Food Chemistry 38:1580-1585. http://dx.doi.org/10.1021/jf00097a032.

[64] Margalith P (1967) Inhibitory effect of gossypol on microorganisms. Journal of Applied Microbiology15:952-953.

[65] Martin SD (1990) Gossypol effects in animal feeding can be controlled. Feedstuffs 62:14-17.

[66]Mbahinzireki GB, Dabrowski K, Lee KJ, El-Saidy D and Wisner ER (2001) Growth, feed utilization and body composition of tilapia (Oreochromis sp.) fed cottonseed meal-based diets in a recirculating system. Aquaculture Nutrition 7:189-200. http://dx.doi.org/10.1046/j.1365-2095.2001.00172.x.

[67]Mickelsen O and Yang MG (1966) Naturally-occurring toxicants in foods. FASEB25: 104-123.

[68] Montamat EE, Burgos C, Burgos GNM, Rovai LE and Blanco A (1982) Inhibitor action of gossypol on enzymes and growth of Trypanosoma cruzi. $\quad$ Science 218:288-289. http://dx.doi.org/10.1126/science.6750791.

[69] Nandeesha MC, De Silva SS and Murthy DK (1995) Use of mixed feeding schedules in fish culture: performance of common carp, Cyprinus carpio L., on plant and animal protein based diets. Aquaculture Research 26(3):161-166. http://dx.doi.org/10.1111/j.13652109.1995.tb00898.x

[70]Nandeesha MC, Gangadhara B and Manissery JK (2002) Further studies on the use of mixed feeding schedules with plant and animalbased diets for common carp Cyprinus carpio (Linnaeus). Aquaculture Research 33:1157-1162. http://dx.doi.org/10.1046/j.13652109.2002.00771.x

[71]Nelson WA (2008) Oilseed Meals as Dietary Protein Sources for Juvenile Nile Tilapia (Oreochromis niloticus L.). PhD Thesis, Institute of Aquaculture University of Stirling, Scotland, UK.

[72]NRC (1993) Nutrient requirements of fish. Washington, D.C., National Academy Press, PP: 114

[73]Ofojekwu PC and Ejike C (1984) Growth response and feed utilization in the tropical cichlid Oreochromis niloticus niloticus (Linn.) fed on cottonseed-based artificial diets. Aquaculture 42:27-36. http://dx.doi.org/10.1016/0044-8486 (84)90310-7.

[74]Ogunji JO (2004) Alternative protein sources in diets for farmed tilapia. CABI International 2004. Nutrition Abstracts and Reviews: Series B 74 (9):23-32.

[75]Pham MA, Lee KJ, Lim SJ and Park KH (2007) Evaluation of cottonseed and soybean meal as partial replacement for fishmeal in diets for juvenile Japanese flounder Paralichthys olivaceus. Fishery Science 73 (4):760-769. http://dx.doi.org/10.1111/j.1444-2906.2007.01394.x.

[76]Portz L and Liebert F (2004) Growth, nutrient utilization and parameters of mineral metabolism in Nile tilapia Oreochromis niloticus (Linnaeus 1758) fed plant-based diets with graded levels of microbial phytase. Journal of Animal Physiology and Animal Nutrition 88:311320. http://dx.doi.org/10.1111/j.1439-0396.2004.00486.x.

[77]Rani N and Hira CK (1993) Effect of various treatments on nutritional quality of fababean (Vicia faba). Journal of Food Science and Technology 30:413-416.

[78]Rao KR, Madhu Ch and Murthy RK (1985) Histopathological and histochemical changes under phosphomidon intoxication in liver of freshwater fish Tilapia mossambica. Proceeding Bulletin Environmental Science 3:20-23.

[79]Rinchard J, Ciereszko A, Dabrowski K and Ottobre J (2000) Effects of gossypol on sperm viability and plasma sex steroid hormones in male sea lamprey, Petromyzon marinus. Toxicology Letters 111:189. http://dx.doi.org/10.1016/S0378-4274 (99)00149-6.

[80]Rinchard J, Mbahinzireki G, Dabrowski K, Lee KJ, Garcia-Abiado M and Ottobre J (2002) Effects of dietary cottonseed meal protein level on growth, gonad development and plasma sex steroid hormones of tropical fish tilapia Oreochromis sp. Aquaculture International 10:1128. http://dx.doi.org/10.1023/A:1021379328778

[81]Robinson EH (1991) Improvement of cottonseed meal protein with supplement lysine in feed for channel catfish. Journal Applied Aquaculture 1:11-14. http://dx.doi.org/10.1300/J028v01n02_01.

[82]Robinson EH and Brent JR (1989) Use of plant proteins in catfish feeds: Replacement of soybean meal with cottonseed meal and replacement of fish meal with soybean meal and cottonseed meal. Jour- 
nal of World Aquaculture Society 20:250-255. http://dx.doi.org/10.1111/j.1749-7345.1989.tb01011.x.

[83]Robinson EH and Daniels WH (1987) Substitution of soybean mea with cottonseed meal in pond feeds for channel catfish reared at low densities. Journal of World Aquaculture Society 18:101-106. http://dx.doi.org/10.1111/j.1749-7345.1987.tb00424.x.

[84]Robinson EH and Li MH (1994) Use of plant proteins in catfish feeds: replacement of soybean meal with cottonseed meal and replacement of fish meal with soybean meal and cottonseed meal. Journal of World Aquaculture Society 25:271-276. http://dx.doi.org/10.1111/j.1749 7345.1994.tb00190.x.

[85]Robinson EH and Li MH (1995) Use of cottonseed meal in aquaculture feeds. In: Lim, C., Sessa, D.J. (Editors.), Nutrition and Utilization Technology in Aquaculture. AOCS Press, Champaign IL, PP: 157-165.

[86]Robinson EH and Rawles SD (1983) Use of defatted, glandless cottonseed flour and meal in channel catfish diets. In: Sweeney, J.M., Sweeney, J.R., Sweeney, K.C., Doerr, P. and Wilson, I. (Editors.), Proceedings of Annual Conference of Southeastern Association of Fish and Wildlife Agencies. Asheville, North Carolina, PP: 358-363.

[87]Robinson, E. H. and T. R. Tiersch. 1995. Effects of long-term feeding of cottonseed meal on growth, testis development and sperm motility of male channel catfish. J World Aquacult. Soc. 26:426-431. http://dx.doi.org/10.1111/j.1749-7345.1995.tb00838.x.

[88]Robinson EH, Rawles SD and Stickney RR (1984b) Evaluation of glanded and glandless cottonseed products in catfish diets. Prog Fish Cult. 46:92-97. http://dx.doi.org/10.1577/1548-8640 (1984)46<92: EOGAGC>2.0.CO; 2.

[89]Robinson EH, Rawles SD, Oldenburg PW and Stickney RR (1984a) Effects of feeding glandless or glanded cottonseed products and Gossypol to Tilapia aurea. Aquaculture 38:145-154 http://dx.doi.org/10.1016/0044-8486 (84)90226-6.

[90]Roehm JM, Lee DJ, Wales JH, Polityka SD and Sinnhuber RO (1970) the effect of dietary sterculic acid on the hepatic lipids of rainbow trout. Lipids 5: 80-84. http://dx.doi.org/10.1007/BF02531099.

[91]Roehm JN, Lee DJ and Sinnhuber RO (1967) Accumulation and elimination of dietary gossypol in the organs of rainbow trout. Journal of Nutrition 92:425.

[92]Sahzadi T, Salim M, Um-E-Kalsoom and Shahzad K (2006) Growth performance and feed conversion ratio (FCR) of hybrid fingerlings (Catla catla x Labeo rohita) fed on cottonseed meal, sunflower mea and bone meal. Pakistan Veterinary Journal 26(4):163-166.

[93]Sajjadi M and Carter CG (2004) Effect of phytic acid and phytase on feed intake growth, digestibility and trypsin activity in Atlantic salmon (Salmo salar, L.). Aquaculture Nutrition 10:135-142. http://dx.doi.org/10.1111/j.1365-2095.2003.00290.x.

[94]Sandberg AS and Svanberg U (1991) Phytate hydrolysis by phytase in cereals; effects on in vitro estimation of iron availability. Journal Food Science 56:1330-1333. http://dx.doi.org/10.1111/j.13652621.1991.tb04765.x

[95] Sealey WM, Lim C and Klesius PH (1997) Influence of the dietary level of iron from iron methionine and iron sulfate on immune response and resistance of channel catfish to Edwardsiella ictaluri. Journal of World Aquaculture Society 28:142-149. http://dx.doi.org/10.1111/j.1749-7345.1997.tb00849.x.

[96]Singh K, Garg SK, Bhatnagar A and Kalla A (2004) Comparison of five different practical diets with various concentrations of dietary protein in nursery ponds: survival and growth of Indian major carp fry. Asian Fishery Science 17:121-134.

[97]Smith RR (1977) recent research involving full-fat soybean meal in salmonid diets. Salmonid1: 8,18 .

[98]Southern LL, Pontif W and Coombs DF (1990) Amino acid supplemented raw soybean diets for finishing swine. Journal of Animal Science 68:2387-2393.

[99]Spinnelli J, Houle CR and Wekell JC (1983) the effect of phytates on the growth of rainbow trout (Salmo gournal airdneri) fed purified diets containing various quantities of calcium and magnesium. Aquaculture 30: 71-83. http://dx.doi.org/10.1016/0044-8486 (83)90153-9.

[100] Srivastava K, Rajesh K, Kamlesh Y and T Sunil P (2008) Devicyprin induced gonadal impairment in a freshwater food fish, Channa punctatus (Bloch). Journal of Environmental Biology 29:187191.

[101] Struthers BJ, Lee DJ and Sinnhuber RO (1975a) Altered lipid metabolism in livers of rainbow trout fed cyclopropenoid fatty acids Experimental Molecular Pathology 23: 181-187. http://dx.doi.org/10.1016/0014-4800 (75)90016-7.

[102] Struthers BJ, Wales JH, Lee DJ and Sinnhuber RO (1975b) Liver composition and histology of rainbow trout fed cyclopropenoid fatty acids. Experimental Molecular Pathology 23: 164-170. http://dx.doi.org/10.1016/0014-4800 (75)90014-3.
[103] Tanksley TD (1990) Cotton-seed meal. In: Thacker, P.A. and Kirkwood, R.N., (Editions.) Nontraditional feed sources for use on swine production, Stoneham, MA/U.S.A.: Butterworth Publishers.

[104] Tilak KS, Veeraiah K and Yacobu K (2001) Studies on histopathological changes in the gill, liver and kidney of Ctenopharyngodon idellus (Valenciennes) exposed to technical fenvalerate and EC 20\%. Pollution Research 20:387-393.

[105] Toko II, Fiogbe ED and Kestemont P (2008) Growth, feed efficiency and body mineral composition of juvenile vundu catfish (Heterobranchus longifilis, Valenciennes 1840) in relation to various dietary levels of soybean or cottonseed meals. Aquaculture Nutrition 14:193-203. http://dx.doi.org/10.1111/j.1365-2095.2007.00518.x.

[106] Usmani N, Jafri AK and Salvi AK (1997) Effect of feeding glanded cottonseed meal on the growth, conversion efficiency and carcass composition of Labeo rohita (Hamilton) Fry. Journal of Aquaculture Tropics 12(1):73-78.

[107] Viola S and G Zohar (1984) Nutrition studies with market size hybrids of tilapia (Oreochromis) in intensive culture. Bamidgeh 36:315 .

[108] Wales JH and Sinnhuber RO (1972) Hepatomas induced by aflatoxin in the sockeye salmon (Oncorhynchus nerka). Journal of the National Cancer Institute 48: 1529

[109] Weatherly AH and HS Zohar (1987) The Biology of Fish Growth. Academic Press, London.

[110] Wichman K, Vaheri A and Lukkainen T (1982) Inhibiting herpes simplex virus type 2 infection in human epithelial cells by gossypol, a potent spermicidal and contraceptive agent. American Journal of Obstetrics \& Gynecology 142:593-594.

[111] Yildirim M, Lim C, Wan PJ and Klesius PH (2003) Growth performance and immune response of channel catfish (Ictalurus punctatus) fed diets containing graded levels of gossypol-acetic acid. Aquaculture 219:751-768. http://dx.doi.org/10.1016/S0044-8486 (03)00062-0.

[112] Yue Y and Zhou Q (2008) Effect of replacing soybean meal with cottonseed meal on growth, feed utilization, and hematological indexes for juvenile hybrid tilapia, Oreochromis niloticus $\times$ Oreochromis aureus. Aquaculture 284:185-189. http://dx.doi.org/10.1016/j.aquaculture.2008.07.030 